\title{
Invasion of HEp-2 cells by strains of Salmonella typhimurium of different virulence in relation to gastroenteritis
}

\author{
GILLIAN R. DOUCE, I. I. AMIN and J. STEPHEN*
}

Microbial Molecular Genetics and Cell Biology Group, School of Biological Sciences, University of Birmingham, PO Box 363, Birmingham B15 2TT

\begin{abstract}
Summary. Experiments to measure the invasiveness of seven strains of Salmonella typhimurium for HEp- 2 cells showed that high inocula (100 bacteria/HEp-2 cell), as used by most workers to synchronise events and to increase the number of bacteria which invade, resulted in recovery of significantly less than $1 \%$ of the original inoculum after treatment with gentamicin to kill extracellular bacteria. Also, the cell culture medium became acidic, and microscopic examination of Giemsa-stained monolayers immediately following gentamicin treatment revealed high concentrations of bacteria associated with the cells. Moreover, with bacterium-cell interaction beyond $2 \mathrm{~h}$, many HEp- 2 cells became rounded, especially with virulent strains W118 and TML. Thus, the biological significance of the quantitative data was uncertain. The fall in $\mathrm{pH}$ and the rounding of HEp-2 cells were prevented by the use of a low $(1: 1)$ bacterium : cell ratio; but the recovery of bacteria after treatment with gentamicin was still lower than expected by microscopic examination. After treatment of cells with Triton X-100 to release bacteria, many remained bound to residual cell nuclei. Additional treatment with a rubber policeman, and vigorous pipetting to disperse aggregates of bacteria and cell debris, increased the recovery to $c .10 \%$ of the initial inoculum after interaction for $2 \mathrm{~h}$, and $30-80 \%$ after $4 \mathrm{~h}$, depending on the strain and experimental conditions. The pattern of invasiveness, but not the absolute count, was highly reproducible on different days and in different hands. However, after interaction exceeding $2 \mathrm{~h}$, the distribution of bacteria was uneven, many cells having no associated organisms, others showing microcolonies. Either this variation does not happen with high inocula, or it is occluded by the high concentration of bacteria associated with the monolayer. Uptake of bacteria depends on the batch of fetal calf serum used in the cell culture medium. The bacterial phenotype is important: bacteria in early or mid log phase entered cells more efficiently, and bacteria grown in Hartley Digest Broth were significantly better at invading HEp-2 cells than those grown in Myosate Broth. Centrifuge-assisted inoculation of $\mathrm{HEp}-2$ cells with bacteria may grossly distort the results, particularly with some avirulent strains.
\end{abstract}

\section{Introduction}

Currently, the most intensively studied aspects of the complex pathogenesis of salmonella infections are attachment to and invasion of intestinal epithelia in vivo or cell culture in vitro, ${ }^{1-14}$ and invasion of and survival in macrophages. ${ }^{10,15-19}$

It is almost canonical that virulent salmonellae are invasive; however, some strains of Salmonella typhimurium are invasive but are avirulent in that they do not induce fluid secretion in the rabbit ileal loop test $(\text { RILT) })^{20,21}$ or cause disease in monkeys. ${ }^{22}$ Virulence may depend upon the degree of invasiveness, the route

Received 23 Nov. 1990; revised version accepted 20 March 1991. *Correspondence should be sent to Dr J. Stephen. or mechanism of invasion, the biological sequelae to invasion, or a combination of these.

Because quantitative study of invasiveness is diffcult in vivo, ${ }^{9}$ cultured cells have been used for assessing invasiveness, and for screening mutants for loss of putative invasins; the significance of such data is most often assessed in mice. ${ }^{7,8,11,12,23}$ These experiments, together with those on the invasion of macrophages and the bacterial determinants of intraphagocytic survival, ${ }^{10,15-19,23}$ probably reflect typhoid-like disease in man and not acute gastroenteritis. A better laboratory animal model for the latter is the RILT developed by Giannella et $a .^{20}$ and since used extensively by Stephen and colleagues. ${ }^{9,21,22,24-28}$ The importance of this distinction cannot be over-emphasised because the incubation period and the clinical signs of these two human diseases are quite different. ${ }^{29}$ 
The need for caution in interpreting data derived from cell culture was shown in the work of Finlay et $a l .{ }^{5}$ who generated six classes of TnphoA mutants of $S$. choleraesuis: whereas wild-type bacteria would attach to, internalise and transcytose MDCK cells, none of the six classes of mutant would do so, yet some mutant strains retained their virulence for mice by the oral route. It was also claimed ${ }^{6}$ that in the process of internalisation new proteins were expressed, and these were said to be involved in the process, although five of the six classes of mutant also expressed them. Clearly these new proteins cannot, as has been more recently stated, ${ }^{14}$ be involved uniquely, if at all, in MDCK cell transcytosis.

The need to establish the role and the mechanism of invasion of gut epithelia by salmonellae and other enteric pathogens is sufficient to warrant continued efforts to develop in-vitro methods which reflect situations in vivo. The objective of our study was to establish conditions whereby virulent strains of $S$. typhimurium could be distinguished from avirulent strains by quantitative assessments of internalisation of HEp-2 cells.

\section{Materials and methods}

\section{Strains of S. typhimurium}

As previously described, ${ }^{25}$ strains TML, W118 and WAKE are virulent in terms of their origin from human clinical disease and their ability to elicit a fluid response in the RILT. Strains LT7, SL1027, M206 and Thax-1 are avirulent as judged by their failure to cause disease in monkeys (reviewed by Stephen et $a{ }^{22}$ ) or fluid secretion in the RILT. ${ }^{21}$ Strain SL1027 was flagellate but non-motile; strain Thax-1 was nonflagellate and non-motile. ${ }^{9}$

\section{Bacterial culture}

Organisms stored at $-70^{\circ} \mathrm{C}$ were plated on MacConkey agar. For cultures in liquid media, Hartley Digest Broth (HDB; Oxoid) was used until production was discontinued; then a sample of a special batch by the same manufacturer was obtained from the Public Health Laboratory Service, Colindale Avenue, London. Myosate Broth (MB; Becton Dickinson Labware, Oxford) was used as an alternative to HDB.

\section{Cell culture}

HEp-2 cells were chosen because of their widespread use and ready availability. The initial seed was a gift from Dr S. Knutton (Institute of Child Health, University of Birmingham). Cells were stored in a nitrogen bank in CMEM (see below) containing dimethylsulphoxide (Sigma) 10\%. They were grown in Falcon tissue-culture flasks $\left(75 \mathrm{~cm}^{2}\right.$; Becton Dickinson) in Minimum Essential Medium (MEM) con- taining $2 \mathrm{~mm}$ L-glutamine and fetal calf serum $10 \%$ (all from Gibco, Paisley), designated complete medium (CMEM). Benzyl penicillin $100 \mathrm{U} / \mathrm{ml}$ and streptomycin sulphate $100 \mu \mathrm{g} / \mathrm{ml}$ were added to this to produce CMEM-A. A second batch of fetal calf serum was obtained from Northumbria Biologicals Ltd, Cramlington; because batches varied, each was tested before purchase for ability to promote invasion of strain TML or W118.

An inoculum of $c .10^{6} \mathrm{HEp}-2$ cells in $1.5 \mathrm{ml}$ was seeded into $15 \mathrm{ml}$ of CMEM-A. Flasks were gassed $\left(\mathrm{CO}_{2} 5 \%\right.$, air $\left.95 \%\right)$, and incubated at $37^{\circ} \mathrm{C}$ for $c .48 \mathrm{~h}$ at which time the cells were confluent. The medium was removed, and the monolayer was washed with $\mathrm{Mg}^{2+}$ - and $\mathrm{Ca}^{2+}$-free phosphate buffered saline (PBS; Gibco); $1 \mathrm{ml}$ of trypsin-EDTA (Gibco) was added, and removed after $30 \mathrm{~s}$. The monolayer was incubated for 3-5 min; the cells were then removed and passed in fresh medium (one flask to three) or used in the invasion assay. Cells were passed no more than 20 times before a fresh seed was taken from the nitrogen bank. Cells were screened regularly with acridine orange and Hoechst stains for contamination with mycoplasmas.

\section{Invasion assay}

The following method represents the final version which evolved from the experiments described in the Results section. Each well in a 24-well tissue-culture tray (Becton Dickinson) was seeded with $(2-4) \times 10^{5}$ HEp- 2 cells in $1 \mathrm{ml}$ of CMEM-A. Trays were gassed in a sealed box, and incubated overnight at $37^{\circ} \mathrm{C}$; the resulting monolayers were usually confluent. Before inoculation of the wells with bacteria, the CMEM-A was removed, and the monolayers were washed with CMEM.

Bacteria were transferred from MacConkey agar by sweep to $10 \mathrm{ml}$ of $\mathrm{HDB}$ or $\mathrm{MB}$ in a $25-\mathrm{ml}$ screwcapped bottle and incubated statically at $37^{\circ} \mathrm{C}$ overnight. This culture was centrifuged, and the bacteria were resuspended in $10 \mathrm{ml}$ of fresh medium, $1 \mathrm{ml}$ of which was transferred into $90 \mathrm{ml}$ of $\mathrm{HDB}$ or $\mathrm{MB}$ and incubated statically at $37^{\circ} \mathrm{C}$ for $3 \mathrm{~h}$ unless specified otherwise. After centrifugation, the bacteria were resuspended at the required cell density (see below) in CMEM, and the suspension was mixed thoroughly with a 1-ml Gilson pipette to disperse any clumps of bacteria.

One $\mathrm{ml}$ of this bacterial suspension was added to each assay well, and the inoculated trays were centrifuged at $300 \mathrm{~g}$ for $30 \mathrm{~min}$ at $37^{\circ} \mathrm{C}$, gassed in sealed boxes and then incubated at $37^{\circ} \mathrm{C}$ for $2 \mathrm{~h}$ unless otherwise stated. Supernates were removed, and monolayers were washed once with PBS; $100 \mu \mathrm{g}$ of gentamicin in $1 \mathrm{ml}$ of CMEM was added to each well, and the trays were gassed and incubated for $1 \mathrm{~h}$ at $37^{\circ} \mathrm{C}$. Supernates were removed, and monolayers were washed twice with PBS. One ml of Triton X-100 (1\% in PBS) was added to each well; after $10 \mathrm{~min}$ a surface- 
sterilised rubber policeman was used to dislodge adherent bacteria and cell debris from the plastic substratum. A pasteur pipette was then used to agitate further the well contents and to disperse bacterial aggregates before counts were estimated. Because it was impossible to pre-determine the exact viable count of the inoculum, invasion was assessed as a percentage of the initial inoculum in each experiment.

\section{Intracellular growth}

The invasion assay was performed as above, in duplicate up to the point of gentamicin addition. Gentamicin was removed from one set of wells after $1 \mathrm{~h}$, as above; in the other sets, gentamicin was left for a further 2,3 or $5 \mathrm{~h}$. The assays were then completed as above. By comparison of the two sets of data, significant intracellular growth could be assessed.

\section{Staining of monolayers}

By seeding with $(2-4) \times 10^{5}$ cells in $1 \mathrm{ml}$ of CMEMA, HEp- 2 cell monolayers were prepared on $12-\mathrm{mm}$ glass coverslips in bijou bottles, previously washed to tissue-culture standard, or in tissue-culture trays. The coverslip monolayers were infected with bacteria, as above, and were then fixed with formal saline ( $\mathrm{HCHO}$ $10 \%$ in saline) and stained with Giemsa stain.

\section{Total and viable counts of bacteria}

Total counts were performed, in a Helber chamber, on organisms killed by formal saline. For viable counts, 10 -fold dilutions were prepared, and $25-\mu 1$ volumes were spread carefully over a quarter of a plate of MacConkey agar. Three samples of each dilution were plated; counts were made preferably from dilutions yielding $40-150$ colonies. A duplicate series of dilutions was used for inocula; a single series of dilutions was made from each well, but the recorded data are usually the means of $c .8-10$ wells.

\section{Results}

\section{High bacterial inocula}

We used initially a bacterium : cell ratio of $100: 1$ and a 2-h period for their interaction. After treatment with gentamicin to kill extracellular bacteria, and Triton X-100 to release intracellular bacteria, significantly less than $1 \%$ of the original bacterial inoculum was recovered (fig. 1). Moreover, this percentage was inversely related to the size of the inoculum (fig. 2). Also, with high inocula, the cell culture medium became acidic.

Microscopic examination of Giemsa-stained monolayers revealed a high concentration of bacteria on the monolayer, and a pleomorphic spectrum from uniformly stained rods to rods with faint bipolar staining

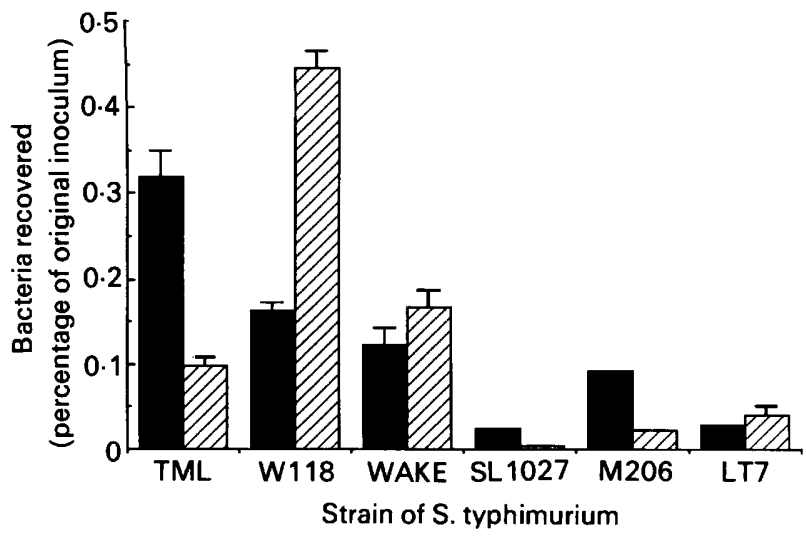

Fig. 1. Recovery of $S$. typhimurium (strains TML, W118, WAKE, SL1027, M206 and LT7) from HEp-2 cells after centrifuge-assisted inoculation with a 3-h bacterial culture to give an initial bacterium : cell ratio of $100: 1$. After interaction for $2 \mathrm{~h}$, and exposure to gentamicin, cells were treated with Triton X-100 alone to release bacteria. The error bars are the SEM of the mean from 10 wells in one experiment $(\boldsymbol{D})$ and from five wells in a second experiment on a different day $(\mathbb{Z}$

(fig. 3). It was not possible to record these types with equal clarity in the same field because many of the bipolar organisms were probably internalised. After interaction for $>2 \mathrm{~h}$, many HEp-2 cells became rounded when virulent strains W118 and TML were used (fig. 3). Thus, the biological significance of the quantitative data obtained with these strains was uncertain; for example, damage to HEp-2 cells may allow the uptake of gentamicin, and the killing of intracellular bacteria. Cell-rounding did not occur with strain WAKE or the avirulent strains.

The disadvantages of high inocula were low recovery of intracellular bacteria, a fall in $\mathrm{pH}$, rounding of the

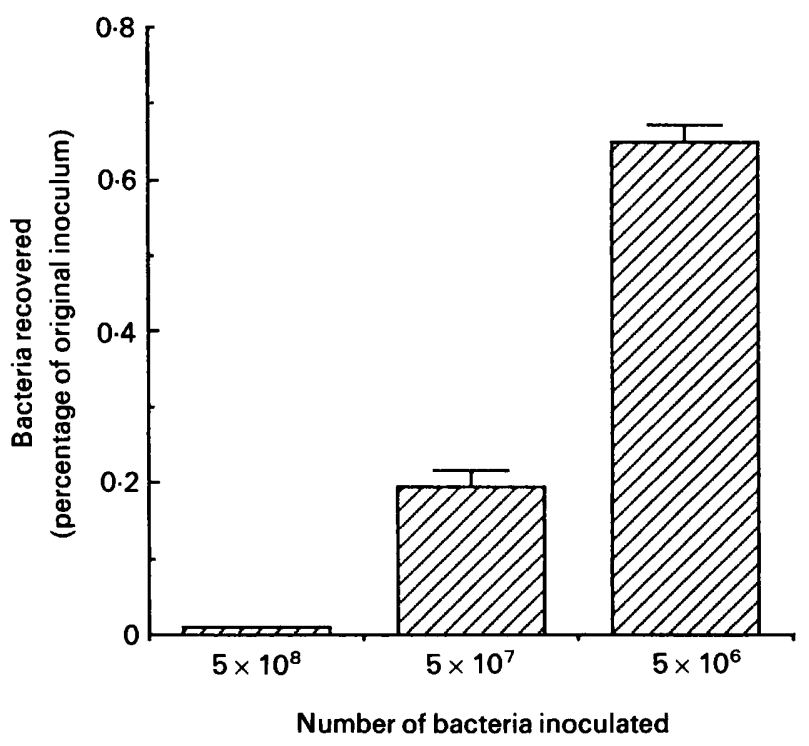

Fig. 2. Recovery of strain TML from HEp-2 cells seeded in the same tray with dilutions of the same bacterial suspension. The procedure was the same as for fig. 1, except that serial dilutions of the bacterial suspension were used, to give initial bacterium : cell ratios of $1000: 1$, $100: 1$ and $10: 1$, by inoculating the wells with $c .5 \times 10^{8}, 5 \times 10^{7}$ and $5 \times 10^{6}$ bacteria, respectively. 

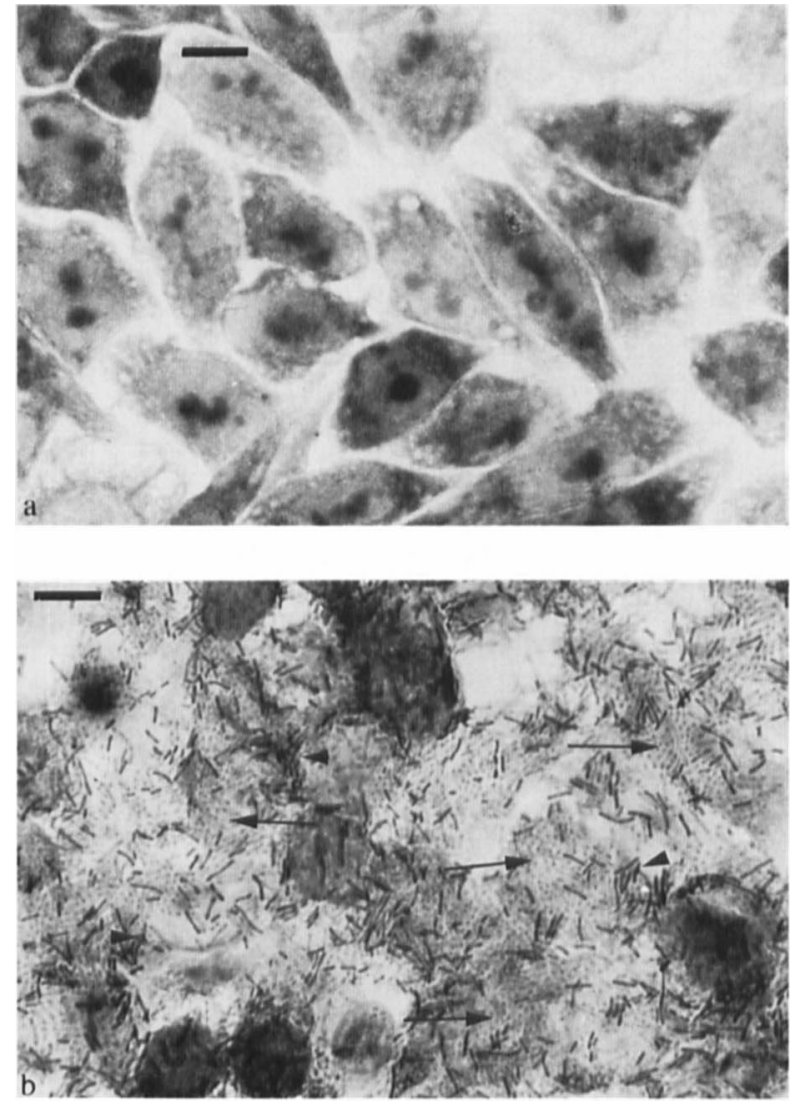

Fig. 3. HEp-2 cells on glass cover slips: a, control; b, inoculated with strain W118 in a bacterium : cell ratio of $100: 1$, allowed to interact for $4 \mathrm{~h}$, treated with gentamicin for $1 \mathrm{~h}$, fixed and Giemsastained. High concentrations of bacteria were associated with the HEp-2 cells; increasing numbers of the latter became rounded as interaction extended beyond $2 \mathrm{~h}$. A spectrum of bacterial morphotypes can be seen, from darkly stained rods (arrow heads) to faintly stained rods with a bipolar appearance (arrows). Bar $=4 \mu \mathrm{m}$.

HEp-2 cells, and a high concentration of bacteria on the monolayer.

\section{Bacterial release}

With high inocula, after Triton X-100 treatment, many organisms remained bound to residual cell nuclei (fig. 4). Subsequent use of a rubber policeman, and vigorous pipetting to disperse aggregates of bacteria and cell debris, increased the recovery of bacteria that survived treatment with gentamicin.

\section{Low bacterial inocula}

In a limited experiment, strains TML, W118 and WAKE were compared over a range of inocula, with only four wells for each inoculum. Table I shows that the highest inoculum for optimal recovery of strains TML and W118 was $10^{5}-\mathrm{a}$ bacterium : cell ratio of c. $1: 1$. This was also the highest ratio that did not lower the $\mathrm{pH}$ or cause cell-rounding with any strain; so, it was chosen for all subsequent work.

A full-scale controlled comparison of all seven strains was carried out for interaction periods of 2 and $4 \mathrm{~h}$ with HEp-2 cells. The recovery of strains TML,

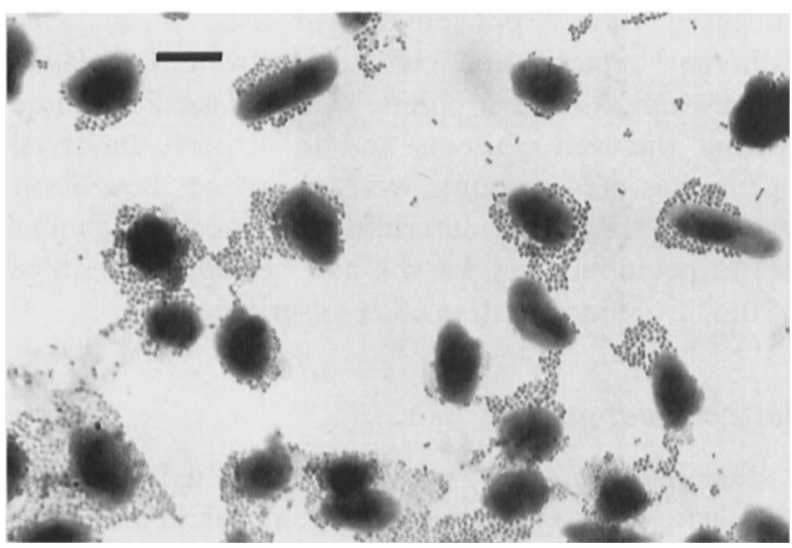

Fig. 4. Residual bacteria bound to cell nuclei or debris after Triton $\mathrm{X}-100$ treatment. These were short bipolar rods similar to some in fig. $3 \mathrm{~b}$. $\mathrm{Bar}=4 \mu \mathrm{m}$.

W118, WAKE and SL1027 increased to $c .10 \%$ of the initial inoculum at $2 \mathrm{~h}$, and up to $30-80 \%$ at $4 \mathrm{~h}$ depending on the strain (fig. 5). These data (fig. 5) represent the pattern obtained in experiments with the same batch of HDB and fetal calf serum. The invasiveness of strain SL1027 was the most variable (see below); it was always greater than that of the other avirulent strains and of virulent strain WAKE, and it was similar to or greater than that of strains TML and W118.

\section{Reproducibility}

The pattern of comparative strain behaviour, but not absolute invasion values, was highly reproducible on different days and in different hands. The range of values, with eight or 10 wells in each experiment, is indicated in table II. The main exception was strain SL1027: in contrast to fig. 5, experiments 3 and 4 ( $2 \mathrm{~h})$ and $1(4 \mathrm{~h})$ show the invasiveness of strain SL1027 to be less than that of strain TML or W118; in the other four experiments, it was similar to or greater than that of strain TML or W118.

\section{Influence of bacterium-cell interaction time}

With interaction times of $>2 \mathrm{~h}$, the distribution of bacteria was uneven: many cells had no associated bacteria, but microcolonies were seen in association with some cells (fig. 6). This phenomenon either does not happen with high inocula, or is occluded by the high density of bacteria associated with the monolayer.

Three experiments were carried out to determine the extent of intracellular growth during exposure of cells to gentamicin for $2-5 \mathrm{~h}$ beyond the standard $1-\mathrm{h}$ gentamicin treatment. Fig. 7 shows that some growth took place, but this was very small compared to the increase in extracellular bacteria obtained for all strains except Thax-1 (fig. 8). Between 1 and $3 \mathrm{~h}$ (fig. $7 \mathrm{a}$ ) and between 1 and $4 \mathrm{~h}$ (fig. $7 \mathrm{~b}$ ) the increases in viable bacteria were $c$. two-fold; between 1 and $6 \mathrm{~h}$ (fig. 7c) c. three-fold. 
Table I. Percentage of original bacterial inoculum recovered from HEp-2 cells after interaction for $4 \mathrm{~h}$ and subsequent treatment with gentamicin

\begin{tabular}{|c|c|c|c|c|c|c|}
\hline \multirow{2}{*}{$\begin{array}{l}\text { Bacterial } \\
\text { strain }\end{array}$} & & \multicolumn{5}{|c|}{$\begin{array}{l}\text { Percentage recovery when the number } \\
\text { of bacteria in the inoculum was }\end{array}$} \\
\hline & & $10^{7 *}$ & $10^{6}$ & $10^{5}$ & $10^{4}$ & $10^{3}$ \\
\hline \multirow[t]{2}{*}{ TML } & & $\begin{array}{r}15.60 \\
17.60 \\
13.60 \\
8.60\end{array}$ & $\begin{array}{l}39 \cdot 13 \\
28 \cdot 98 \\
38 \cdot 30 \\
20 \cdot 40\end{array}$ & $\begin{array}{l}44 \cdot 15 \\
38.96 \\
56 \cdot 00 \\
38 \cdot 90\end{array}$ & $\begin{array}{l}28 \cdot 57 \\
25 \cdot 71 \\
48 \cdot 00 \\
50 \cdot 00\end{array}$ & $\begin{array}{l}26.66 \\
17.77 \\
35.00 \\
56.00\end{array}$ \\
\hline & $\begin{array}{l}\text { Mean } \\
\text { SEM }\end{array}$ & $\begin{array}{c}13.85 \dagger \\
1.93\end{array}$ & $\begin{array}{r}31 \cdot 70 \\
4 \cdot 41\end{array}$ & $\begin{array}{r}44 \cdot 50 \\
4 \cdot 03\end{array}$ & $\begin{array}{r}38 \cdot 07 \\
6 \cdot 35\end{array}$ & $\begin{array}{r}33 \cdot 86 \\
8 \cdot 18\end{array}$ \\
\hline \multirow[t]{2}{*}{ W118 } & & $\begin{array}{r}12 \cdot 53 \\
9 \cdot 25 \\
11 \cdot 30 \\
8.60\end{array}$ & $\begin{array}{l}28 \cdot 98 \\
23 \cdot 18 \\
30 \cdot 00 \\
31 \cdot 00\end{array}$ & $\begin{array}{l}54 \cdot 87 \\
36 \cdot 87 \\
47 \cdot 00 \\
61 \cdot 00\end{array}$ & $\begin{array}{l}50 \cdot 00 \\
51 \cdot 38 \\
40 \cdot 00 \\
56 \cdot 00\end{array}$ & $\begin{array}{l}26.00 \\
66.00 \\
32.00 \\
44.00\end{array}$ \\
\hline & $\begin{array}{l}\text { Mean } \\
\text { SEM }\end{array}$ & $\begin{array}{r}10 \cdot 42 \\
0.91\end{array}$ & $\begin{array}{r}28 \cdot 29 \\
1 \cdot 75\end{array}$ & $\begin{array}{r}49 \cdot 94 \\
5 \cdot 21\end{array}$ & $\begin{array}{r}49 \cdot 25 \\
3 \cdot 35\end{array}$ & $\begin{array}{r}42.00 \\
8.83\end{array}$ \\
\hline \multirow[t]{2}{*}{ WAKE } & & $\begin{array}{l}3 \cdot 14 \\
3 \cdot 71 \\
7 \cdot 90 \\
6 \cdot 40\end{array}$ & $\begin{array}{r}5 \cdot 53 \\
4 \cdot 61 \\
8 \cdot 20 \\
12 \cdot 40\end{array}$ & $\begin{array}{l}8 \cdot 00 \\
7 \cdot 33 \\
7 \cdot 90 \\
8 \cdot 10\end{array}$ & $\begin{array}{r}5 \cdot 00 \\
7 \cdot 22 \\
14 \cdot 30 \\
15 \cdot 40\end{array}$ & $\begin{array}{r}26 \cdot 31 \\
7 \cdot 36 \\
11 \cdot 70 \\
3.90\end{array}$ \\
\hline & $\begin{array}{l}\text { Mean } \\
\text { SEM }\end{array}$ & $\begin{array}{l}5 \cdot 29 \\
1 \cdot 12\end{array}$ & $\begin{array}{l}7.69 \\
1.75\end{array}$ & $\begin{array}{l}7 \cdot 83 \\
0 \cdot 17\end{array}$ & $\begin{array}{r}10 \cdot 48 \\
2 \cdot 57\end{array}$ & $\begin{array}{r}12 \cdot 32 \\
4 \cdot 93\end{array}$ \\
\hline
\end{tabular}

* In each experiment, the highest inoculum in the 10 -fold dilutions was c. $(1-2) \times 10^{7}$ bacteria.

$\dagger$ With each dilution, two wells of monolayers were inoculated, and the experiment was repeated by another worker. The means are derived from the pooled data of two experiments. In every other case (table II; figs. 1, 2, $5,7-10)$ data have not been pooled from different experiments.

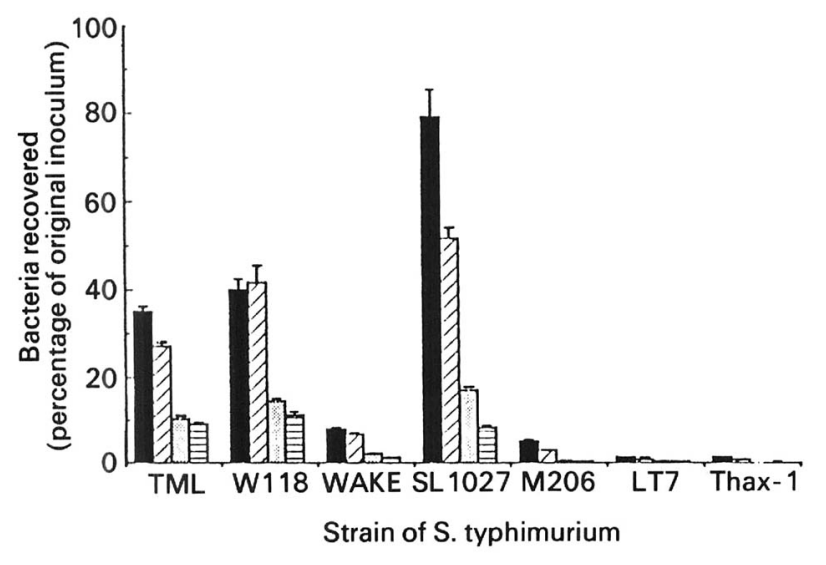

Fig. 5. Recovery of strains TML, W118, WAKE, SL1027, M206, LT7 and Thax-1 from HEp-2 cells after centrifuge-assisted inoculation with a 3-h bacterial culture to give an initial bacterium : cell ratio of $1: 1$. After interaction for $2 \mathrm{~h}$ (圈, 目) or $4 \mathrm{~h}(\boldsymbol{\square}$, $\bigotimes$ ) and exposure to gentamicin, cells were treated with Triton $\mathrm{X}$ 100 and with a rubber policeman to release bacteria. The data shown for each strain were from separate experiments performed on different days. The error bars are the SEM of the mean from 810 wells. (Viable counts on the supernates removed before the addition of gentamicin are shown in fig. 8.)

\section{Influence of fetal calf serum}

As reported in a similar study, ${ }^{30}$ there were significant differences between batches of fetal calf serum, but the reason was not established. Strain SL1027, which tended to give more variable results than the others, was most affected by changes in batches of serum.

\section{Influence of bacterial phenotype}

Overnight cultures were found to be less invasive than those in log phase; 3 -h cultures were adopted as standard. Also, significant differences were observed between bacteria grown in MB and those grown in HDB (fig. 9).

\section{Influence of centrifugation of bacterial inoculum on to cell monolayer}

One possible explanation for the seemingly greater invasiveness sometimes exhibited by the avirulent strain SL1027 over that of the virulent strains (see fig. 5) was that the result was artefactual. Since strain SL1027 was fiagellate but not motile, the effect of centrifuging the inoculum on to the HEp-2 cell monolayer was considered. A comparison was therefore made between strains W118 and SL1027, with and without centrifugation. Omission of the centrifugation step reduced the invasiveness of SL1027 to a level significantly below that of W118 (fig. 10 a) and depressed the absolute degree of invasiveness of both strains W118 and SL1027 (fig. 10 a,b).

\section{Discussion}

This work reveals the influence of several technical factors on the interaction of bacteria and host cells in 
Table II. Percentage of original bacterial inoculum recovered from gentamicin-treated HEp- 2 cells after previous interaction with bacteria for $2 \mathrm{~h}$ or $4 \mathrm{~h}$

\begin{tabular}{|c|c|c|c|c|c|c|c|}
\hline \multirow{3}{*}{$\begin{array}{c}\text { Bacterial } \\
\text { strain }\end{array}$} & \multicolumn{7}{|c|}{ Mean (SEM) percentage recovery after initial interaction for } \\
\hline & \multicolumn{4}{|c|}{$2 \mathrm{~h}$ in experiment no. ${ }^{*}$} & \multicolumn{3}{|c|}{$4 \mathrm{~h}$ in experiment no. ${ }^{*}$} \\
\hline & 1 & 2 & 3 & 4 & 1 & 2 & 3 \\
\hline W118 & $14.4(0.71)$ & $11.4(0.71)$ & $11.4(0.55)$ & $12 \cdot 7(0.90)$ & $43.8(2.63)$ & $39.9(2.45)$ & $41.6(3.88)$ \\
\hline TML & $10.4(0.72)$ & $9.2(0.52)$ & $9 \cdot 1(0.52)$ & $11.7(0.49)$ & $31.5(1.57)$ & $35.0(1.39)$ & $27.0(1.06)$ \\
\hline SL1027 & $17 \cdot 2(0.56)$ & $8.2(0.43)$ & $5.9(0.49)$ & $4 \cdot 3(0 \cdot 22)$ & $25 \cdot 4(1 \cdot 22)$ & $79 \cdot 2(6 \cdot 37)$ & $51 \cdot 6(2 \cdot 38)$ \\
\hline
\end{tabular}

* In each experiment, a minimum of eight wells of HEp-2 monolayers was inoculated with an initial bacterium :cell ratio of $1: 1$. Note the low SEM values.
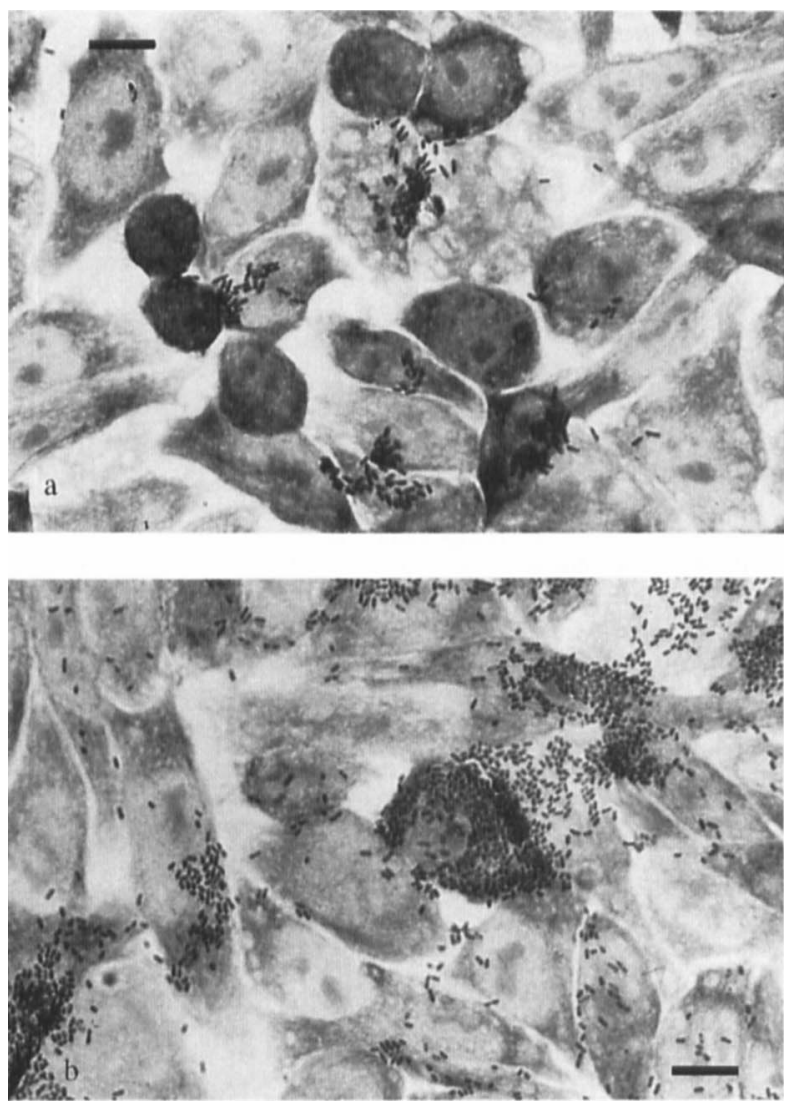

Fig. 6. The distribution of strain W118 on HEp-2 cells after centrifuge-assisted inoculation with an initial bacterium :cell ratio of $1: 1$. The size of the microcolonies increased with time of interaction: $\mathbf{a}, 2 \mathrm{~h} ; \mathbf{b}, 4 \mathrm{~h}$. The morphology and staining intensity of the bacteria was more constant when these low inocula were used. $\mathrm{Bar}=4 \mu \mathrm{m}$.

vitro. Most workers use high bacterial inocula to maximise the number of synchronous productive attachment and entry events occurring in a short period of time (Escherichia coli, S. typhimurium, Yersinia pseudotuberculosis and $Y$. enterocolitica with HEp-2 cells; ${ }^{2} S$. choleraesuis, Shigella flexneri and $Y$. enterocolitica with CHO, HEp-2, and MDCK cells; ${ }^{3}$ S. typhi with Henle cells; $;^{7}$ S. typhimurium with Caco2 cells and $\mathbf{J} 774$ macrophage cell line ${ }^{10} S$. typhimurium with HEp-2 cells ${ }^{13}$ ). Our data raise the possibility that high numbers of bacteria could lead to host-cell

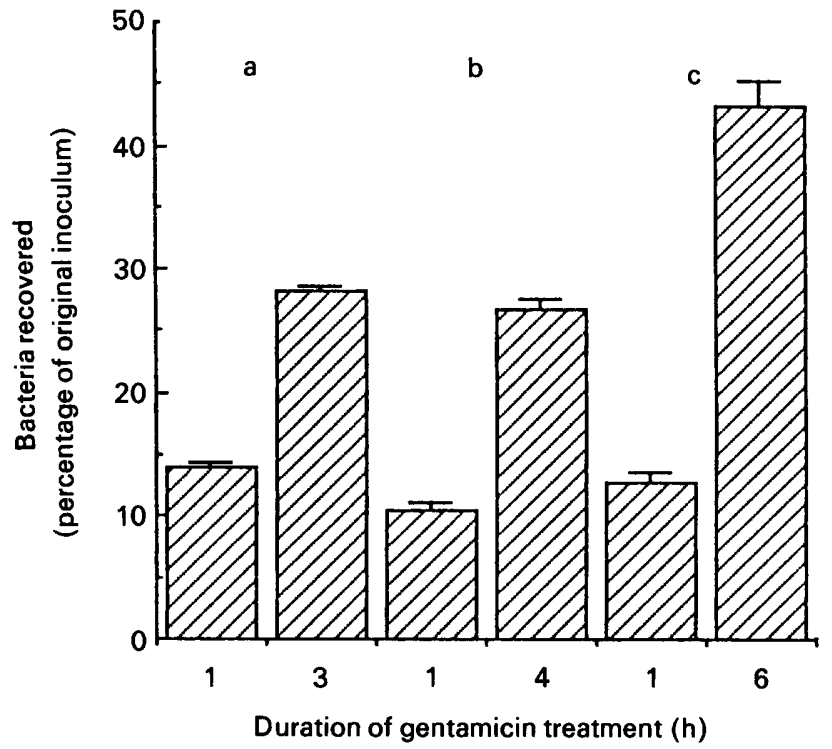

Fig. 7. Multiplication of strain W118 in HEp-2 cells inoculated to give an initial bacterium : cell ratio of $1: 1$. Intracellular multiplication was assessed in three experiments in which the standard 1-h exposure to gentamicin was compared in replicate sets of wells with exposure times of a, $3 \mathrm{~h} ; \mathbf{b}, 4 \mathrm{~h} ; \mathbf{c}, 6 \mathrm{~h}$.

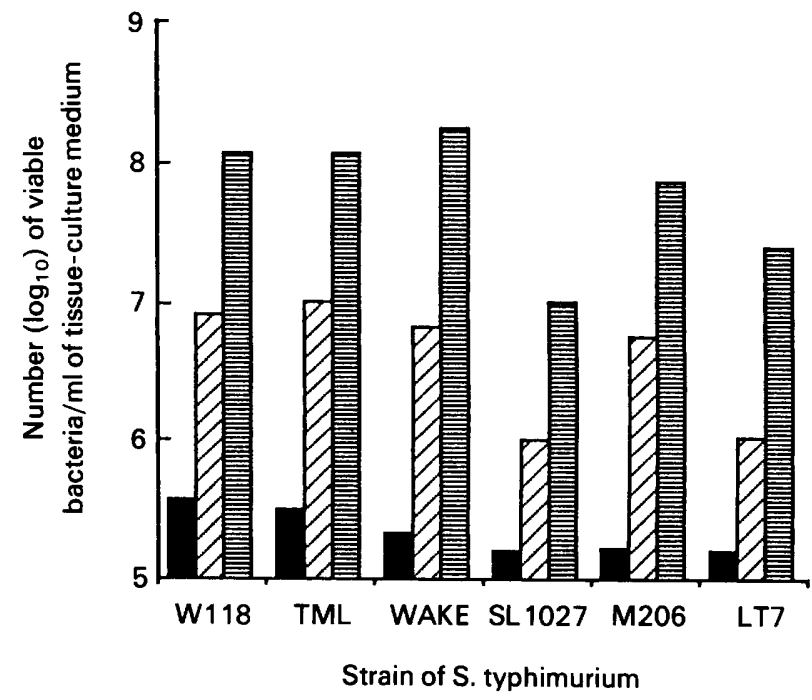

Fig. 8. Extracellular multiplication of strains W118, TML, WAKE SL1027, M206 and LT7. Viable counts on the supernates (fig. 5) before addition of gentamicin, were made after bacterium-cell interaction times of $0 \mathrm{~h}(\mathbb{\square}), 2 \mathrm{~h}(\mathbb{Z}), 4 \mathrm{~h}($ 目); the doubling time was c. $30 \mathrm{~min}$. 


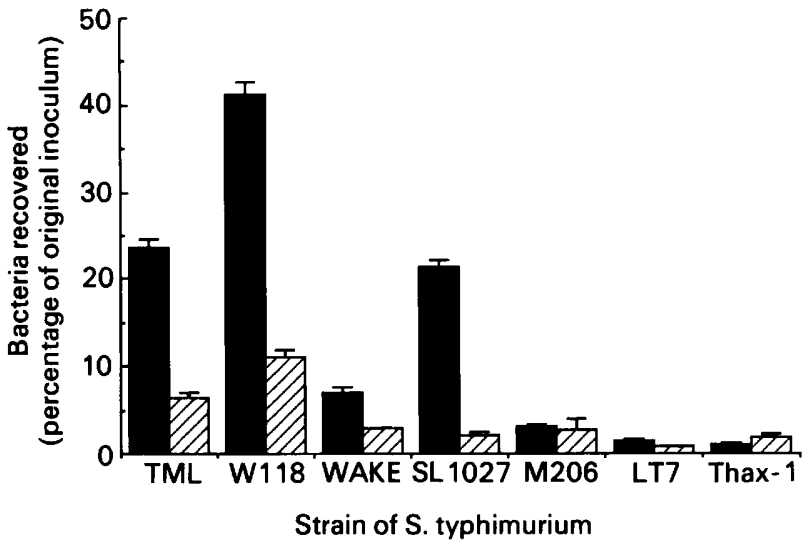

Fig. 9. Recovery of strains TML, W118, WAKE, SL1027, M206, LT7 and Thax-1 from HEp-2 cells after centrifuge-assisted inoculation with a 3-h bacterial culture in HDB $(\square)$ or MB $(\square)$ to give an initial bacterium: cell ratio of $1: 1$. Subsequent interaction lasted $4 \mathrm{~h}$. The data are from two experiments and show consistently greater invasion by virulent strains of the HDB phenotype.

damage and allow entry of gentamicin, and hence reduce the recovery of viable intracellular bacteria. Even if there were strain differences, conditions should be arranged such that the damage caused by the most cytotoxic strain would be minimised. Use of a rubber policeman after detergent treatment, and vigorous pipetting in dilution for viable counts, greatly increased the counts. The latter procedure has recently been adopted, ${ }^{14}$ but we know of no report on the use of physical methods to remove the bacteria.

The absolute values of invasiveness of a strain did vary between experiments, as reported in a similar study. ${ }^{10}$ However, apart from strain SL1027 which gave highly variable results, within each experiment the pattern of our results was highly reproducible

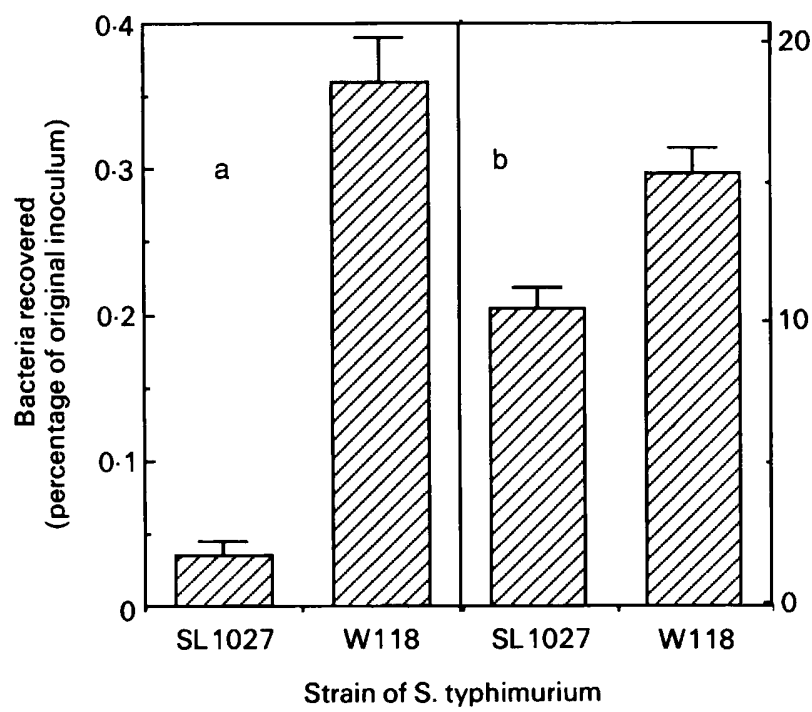

Fig. 10. Recovery of strains W118 and SL1027 from HEp-2 cells after (a) non-centrifuge-assisted and (b) centrifuge-assisted inoculation with a 3-h bacterial culture to give an initial bacterium :cell ratio of $1: 1$. Subsequent interaction lasted $2 \mathrm{~h}$. On this occasion the centrifuge-assisted invasiveness of strain SL1027 was less than that of strain W118 (cf. fig. 5 where a different batch of fetal calf serum was used). (table II). Therefore, this test could be used to screen mutant strains for loss of invasiveness when compared to the wild-type parent in the same experiment.

Great care was taken to ensure that bacterial inocula applied to the monolayers were single-cell suspensions. However, microcolonies were always seen at $2 \mathrm{~h}$ after inoculation. It has not yet proved possible to infect each cell in the monolayer with only one or a few organisms. It seems important to know whether the microcolonies resulted from a small number of host cells expressing the necessary receptors to which bacteria must first attach and thereby stimulate their uptake - i.e., was dependent on the surface phenotype of the cell-or, as has been suggested for isolated rat enterocytes, ${ }^{1}$ whether attachment of a few bacteria promotes the release of a chemotaxin which results in focal aggregation of bacteria and ingestion of a microcolony. This is under study at present, because it might help to explain the similar phenomenon of microcolony ingestion in vivo. ${ }^{9,31,32}$

With high inocula, pleomorphism (fig. 3) was always observed, but not with low inocula (fig. 6). We found the faint bipolar staining to be typical of cells in stationary or decline phase in batch culture (unpublished observations). Therefore, this may reflect exhaustion of the extracellular culture medium, as indicated by the drop in $\mathrm{pH}$. Also, because many of these bipolar bacteria appeared to be intracellular, they may indicate a less favourable environment. The growth rates implicit in fig. 7 support this, as does the bipolar appearance of released bacteria in fig. 4 .

The data on strain SL1027 are important because, without them, there was a good correlation between invasiveness and virulence: virulent strains TML, W118 and WAKE were more invasive than avirulent strains LT7, M206 and Thax-1. In many experiments (e.g., fig. 5) strain SL1027 was the most invasive of the seven tested; yet it is avirulent. ${ }^{20,21}$ It is invasive, also, as judged by its recovery in enrichment culture from internal organs after intestinal inoculation, ${ }^{21}$ but it is relatively non-invasive as judged by immunofluorescent antibody analysis of intestinal mucosa from RILs inoculated with it (unpublished observations). This raises questions about the validity of the HEp- 2 test to distinguish virulent from avirulent strains, and about the use of the test as a primary screen for detecting mutant strains that were potentially less invasive in the gut than their wild-type parents. HEp-2 cellseven under the optimised conditions described heremay not reflect sufficiently well the susceptibility to invasion of gut epithelial cells in vivo. However, strain SL1027 seems peculiar, and our confidence in the use and interpretation of test data remains. When strain SL1027 was applied to HEp-2 cells, without centrifugation on to the monolayer, the recovery of intracellular bacteria fell, as might have been expected, and its invasiveness was very much lower than that of strain W118 (fig. 10). It may be significant that strain SL1027 is flagellate and non-motile and that, in studies on association with gut cells in vitro ${ }^{9}$ which did not 
involve centrifugation, it associated less well than strains TML and W118 but better than strain Thax-1 which is non-flagellate. If motility increases the frequency of productive attachment and entry, and if flagella are involved in attachment, these observations appear reasonable. Two important points arise from such considerations. First, such an interpretation is possible only by virtue of prior knowledge of relevant biological properties: one could not have extrapolated in the reverse direction from HEp-2 cell data to gut. Second, if the centrifugal step is to be retained (as indeed it must for logistical reasons) for initial screening of large numbers of mutant strains for loss of invasiveness, the possibility must be recognised that some mutants may show an apparent increase in invasiveness when compared with their wild-type parents: these would then need to be rigorously tested in a non-centrifuge-assisted assay.

Comparison of strains TML, W118 and WAKE shows that WAKE was consistently less invasive than the other two, though all three appear virulent by their clinical origin and their behaviour in RILTs. It seems more than coincidence that the invasiveness described here closely parallels the influx of polymorphonuclear (PMN) cells induced by these strains. ${ }^{25}$ Together, these data highlight the multifactorial and quantitative nature of the virulence of $S$. typhimurium. The invasiveness of strain WAKE, though less than that of strains TML and W118, must be sufficient to initiate the next step in the biological sequel leading to clinical signs. If that next step is induction of a PMN influx ${ }^{25,26}$ then sufficient PMNs are recruited by strain WAKE to initiate the complex process of toxin processing and release which, as has been argued, ${ }^{25,26}$ could be involved in the induction of fluid secretion.

Invasiveness is also phenotypically determined;

\section{References}

1. Lindquist BL, Lebenthal E, Lee P-C, Stinson MW, Merrick JM. Adherence of Salmonella typhimurium to smallintestinal enterocytes of the rat. Infect Immun 1987; 55: 3044-3050.

2. Small PLC, Isberg RR, Falkow S. Comparison of the ability of enteroinvasive Escherichia coli, Salmonella typhimurium Yersinia pseudotuberculosis, and Yersinia enterocolitica to enter and replicate within HEp-2 cells. Infect Immun 1987; 55: 1674-1679.

3. Finlay BB, Falkow S. Comparisons of the invasion strategies used by Salmonella choleraesuis, Shigella flexneri and Yersinia enterocolitica to enter cultured animal cells endosome acidification is not required for bacterial invasion or intracellular replication. Biochimie 1988; 70 1089-1099.

4. Finlay BB, Gumbiner B, Falkow S. Penetration of Salmonella through a polarized Madin-Darby canine kidney epithelial cell monolayer. J Cell Biol 1988; 107: 221-230.

5. Finlay BB, Starnbach, MN, Francis CL et al. Identification and characterization of TnphoA mutants of Salmonella that are unable to pass through a polarized MDCK epithelial cell layer. Mol Microbiol 1988; 2: 757-766.

6. Finlay BB, Heffron F, Falkow S. Epithelial cell surfaces induce Salmonella proteins required for bacterial adherence and invasion. Science $1989 ; 243$ : 940-943. organisms grown in MB were consistently less invasive than those grown in HDB. If the genes controlling invasion (inv) are identified and characterised in ongoing studies, it may be possible to study the physiological regulation of these genes by analysis of the two media. Also, expression of cholera toxin related antigen (CTRA) is similarly regulated, ${ }^{28}$ and CTRA may be a precursor of an active CT-like $\operatorname{toxin}^{27,28}$ which may be involved in the induction of fluid secretion. ${ }^{25}$ Inv and ctra may be co-ordinately regulated.

Because invasiveness is measured by the number of bacteria recovered after treatment with gentamicin, and because the number recovered increases with time, it is important to apportion the increase between bacteria which continue to invade during the experiment and those which have multiplied intracellularly. This could be crucial in the comparison of fast-growing invasive parent strains with mutants which grow slowly. The two-fold increase in the first $4 \mathrm{~h}$ (fig. $7 \mathrm{a}, \mathrm{b}$ ) may be merely the completion of multiplication to which invading bacteria were already committed; this would be consistent with electronmicrographs ${ }^{9}$ that show dividing cells entering enterocytes. The increase seen by $6 \mathrm{~h}$ (fig. 7c) may represent further intracellular growth of organisms, the rate of which was vastly slower than that occurring extracellularly. Shorter and longer periods of incubation in the presence of gentamicin would be required to establish these points.

It is with pleasure that we acknowledge final year undergraduate students Janet Bradley, Lisa Topping, Lisa Wilcockson and $\mathbf{N}$. Gracie-Langrick for the data on HDB and MB media comparisons. We thank the Medical Research Council for a studentship to G.R.D., The Association of Commonwealth Universities for a scholarship to I.I.A., and Gateway Foodmarkets Ltd for a financial contribution.

7. Elsinghorst EA, Baron LS, Kopecko DJ. Penetration of human intestinal epithelial cells by Salmonella: molecular cloning and expression of Salmonella typhi invasion determinants in Escherichia coli. Proc Natl Acad Sci USA 1989; 86: 51735177.

8. Miller I, Maskell D, Hormaeche C, Johnson K, Pickard D, Dougan G. The isolation of orally attenuated Salmonella typhimurium following TnphoA mutagenesis. Infect Immun 1989; $57: 2758-2763$

9. Worton KJ, Candy DCA, Wallis TS et al. Studies on early association of Salmonella typhimurium with intestinal mucosa in vivo and in vitro: relationship to virulence. $J \mathrm{Med}$ Microbiol 1989; 29: 283-294.

10. Gahring LC, Heffron F, Finlay BB, Falkow S. Invasion and replication of Salmonella typhimurium in animal cells. Infect Immun $1990 ; 58$ : 443-448.

11. Galán JE, Curtiss R. Cloning and molecular characterization of genes whose products allow Salmonella typhimurium to penetrate tissue culture cells. Proc Natl Acad Sci USA 1989; 86: $6383-6387$

12. Galán JE, Curtiss R. Expression of Salmonella typhimurium genes required for invasion is regulated by changes in DNA supercoiling. Infect Immun 1990; 58: 1879-1885.

13. Ernst RK, Dombroski DM, Merrick JM. Anaerobiosis, type 1 fimbriae, and growth phase are factors that affect invasion of HEp-2 cells by Salmonella typhimurium. Infect Immun 1990; 58: 2014-2016. 
14. Lee CA, Falkow S. The ability of Salmonella to enter mammalian cells is affected by bacterial growth state. Proc Natl Acad Sci USA 1990; 87: 4304-4308.

15. Fields PI, Swanson RV, Haidaris CG, Heffron F. Mutants of Salmonella typhimurium that cannot survive within the macrophage are avirulent. Proc Natl Acad Sci USA 1986; 83: 5189-5193.

16 Fields PI, Groisman EA, Heffron F. A Salmonella locus that controls resistance to microbicidal proteins from phagocytic cells. Science $1989 ; 243$ : 1059-1062.

17. Miller SI, Kukral AM, Mekalanos JJ. A two-component regulatory system (phoP phoQ) controls Salmonella typhimurium virulence. Proc Natl Acad Sci USA 1989; 86: 5054 5058.

18. Groisman EA, Chiao E, Lipps CJ, Heffron F. Salmonella typhimurium phoP virulence gene is a transcriptional regulator. Proc Natl Acad Sci USA 1989; 86: 7077-7081.

19. Groisman EA, Saier MH. Salmonella virulence: new clues to intramacrophage survival. TIBS 1990; 15: 30-33.

20. Giannella RA, Formal SB, Dammin GJ, Collins H. Pathogenesis of salmonellosis. Studies of fluid secretion, mucosal invasion, and morphologic reaction in the rabbit ileum. $J$ Clin Invest 1973; 52: 441-453.

21. Wallis TS, Starkey WG, Stephen J, Haddon SJ, Osborne MP, Candy DCA. Enterotoxin production by Salmonella typhimurium strains of different virulence. J Med Microbiol 1986; $21: 19-23$.

22. Stephen J, Wallis TS, Starkey WG, Candy DCA, Osborne MP, Haddon SJ. Salmonellosis: in retrospect and prospect. In Evered D, Whelan J (eds) Microbial toxins and diarrhoeal disease. Ciba Foundation Symposium 112. London, Pitman. 1985: 175-192.

23 Miller SI, Mekalanos JJ. Constitutive expression of the PhoP regulon attenuates Salmonella virulence and survival within macrophages. J Bacteriol 1990; 172 : 2485-2490.
24. Wallis TS, Starkey WG, Stephen J, Haddon SJ, Osborne MP, Candy DCA. The nature and role of mucosal damage in relation to Salmonella typhimurium-induced fluid secretion in the rabbit ileum. J Med Microbiol 1986; 22: 39-49.

25. Wallis TS, Hawker RJH, Candy DCA et al. Quantification of the leucocyte influx into rabbit ileal loops induced by strains of Salmonella typhimurium of different virulence. $J$ Med Microbiol 1989; 30: 149-156.

26. Wallis TS, Vaughan ATM, Clarke GJ et al. The role of leucocytes in the induction of fluid secretion by Salmonella typhimurium. J Med Microbiol 1990; 31: 27-35.

27. Clarke GJ, Qi G-M, Wallis TS et al. Expression of an antigen in strains of Salmonella typhimurium which reacts with antibodies to cholera toxin. J Med Microbiol 1988; 25: 139 146.

28. Qi G-M, Clarke GJ, Wallis TS, Stephen J. The influence of cultural conditions on the expression in Salmonella typhimurium of an antigen related to cholera toxin. $J$ Med Microbiol 1989; 30: 213-217.

29. Candy DCA, Stephen J. Salmonella. In: Farthing MJG, Keusch GT (eds) Enteric infection. Mechanisms, manifestations and management. London, Chapham and Hall Medical. 1989: 289-298.

30. Shaw JH, Falkow S. Model for invasion of human tissue culture cells by Neisseria gonorrhoeae. Infect Immun 1988; 56 : $1625-$ 1632.

31. Takeuchi A. Electron microscope studies of experimental salmonella infection. I. Penetration into the intestinal epithelium by Salmonella typhimurium. Am J Pathol 1967; 50: $109-136$

32. Takeuchi A, Sprinz H. Electron microscope studies of experimental salmonella infection in the preconditioned guinea pig. II. Response of the intestinal mucosa to invasion by Salmonella typhimurium. Am J Pathol 1967; 51 : 137-161. 